\title{
Smart Device Usage Frequency and Usage Level for Learning English
}

\author{
https://doi.org/10.3991/ijet.v14i19.10003
}

\author{
Areej Alsanosi \\ Master's TEFL student, Taibah University, KSA
}

\author{
Abeer Aharbi \\ TEFL Teacher, Almahad District, KSA \\ Safaa Alhebaishi ${ }^{(凶)}$ \\ Taibah University, Medina, KSA \\ dr.safaa93@yahoo.com
}

\begin{abstract}
This study investigates the frequency and level at which intermediate school students use smart devices to learn English as a foreign language. To achieve the study objective, a questionnaire with close-ended responses was developed and administered to a sample of 50 female students who owned smart devices and used them for learning English outside the classroom. An analysis of the collected data indicated that the usage level of smart devices among intermediate school students is high. The results revealed that the learning purposes with the highest usage frequency were "sending assignments to the teacher"," learning more about any topic", and "receiving feedback from teacher and colleagues". Whereas the purposes with the lowest usage frequency were "learning grammatical structures", "finding reading activities" and "improving the writing skill". The study recommends that education system and policy makers allow students to use their smart devices in English classes and encourage teachers to acquire the skills necessary for blending smart devices with traditional teaching methods.
\end{abstract}

Keywords - Smart devices, Intermediate school, Learning English

\section{$1 \quad$ Introduction and Background}

The technological revolution is spreading into and dominating all aspects of life. The use of smart devices, particularly smart phones and tablets has become more widespread among young people than others. These devices are now considered essential tools for playing games, taking photos, listening to music, watching movies, browsing the Internet and staying connected with others [15]. Smart devices have many attractive characteristics; thus, their usage encouraged among young people.

Recent advancements in smart devices have resulted in changes in teaching and learning approaches. The rapid growth of smart devices, and wireless communication 
networks, as well as the physical features of these devices and their high usage have provided educators with significant tools that drive an emerging trend in mobile learning [22]. The popularity of smart devices arises from the powerful capabilities they offer to users. For example, they are portable, handheld, have high memory and processing capacities to carry out various procedures such as storing documents, uploading and downloading files, taking pictures, recording videos, playing games, listening to music, browsing the Internet, and accessing shopping websites. In addition to making calls, users can send and receive messages, access social networks, search for information, check the weather and utilize global positioning systems. Other features include video and audio recording, web browsers, multimedia apps, clocks, cameras, calculators, Bluetooth, games, and chatting and communication apps (Skype, Viber, Telegram, and WhatsApp) [43].

Incorporating smart devices in education can positively impact the learning process and result in new student-centered pedagogies. Using smart devices in schools has many advantages over traditional teaching and learning. Such advantages result from the distinctive features of smart devices such as their ubiquity, usability, flexibility, accessibility, and connectivity [8].

Smart devices offer various benefits to both students and teachers. Experts believe that the use of smart phones in the classroom provides students with the opportunity to develop critical thinking skills, collaborate with peers and receive immediate feedback [21], [10], [41], [20]. Mobile devices have various benefits for education. They enable learners to take part in interactive assignments such as classroom polls, they can help students complete blog posts or podcasting assignments, and they can be used as notepads or as alarms for setting study reminders [1]. Smart phones may also give teachers the ability to access more authentic materials to assist the development and delivery of lessons and give them a chance to provide students with additional resources for relevant topics. Smart phones bring a large number of real learning possibilities that are convenient and compatible with mobile lifestyles [26]. It is claimed that smart devices can help teaching and learning styles and enable personalized, situated and authentic learning. Authentic learning refers to learning in the context of real-world problems that are related to the students' lives [36]. There are also many benefits for students who use smart phones in learning:

- Smart phones provide them with flexibility, so they are able to learn anytime and anywhere

- Smart phones provide learners with many features including the ability to access information, record data, and create podcasts [12].

Learners can use smart mobile devices to access digital libraries, find quizzes, participate in lessons and tutorials, receive lectures, and participate in virtual learning communities [18]. Smart phones are interesting tools that can make education accessible to rural children in places and times better than attending public schools. A 26week study was conducted to show the extent to which children will make use of smart devices like iPads for educational benefits. The study resulted in a high level of academic learning and motivation [27]. 
Currently, smart devices are used to teach and learn foreign languages. This includes various applications that help users increase their language proficiency, improve various language skills, and make learning more enjoyable [13]. App stores for smart device like Apple's App Store and Google Play now offer users countless apps for free or at nominal cost. Language learners use their smart phones to enhance formal/informal language learning. Smart devices enable students to access information and collect, store, share and organize data. They can easily conduct research, access learning materials, and interact with people outside the classroom when they are connected via Wi-Fi.

Reviewing the literature of using smart devices in learning English revealed that they are effective tools. For example, [25] conducted a study that aimed at evaluating the use of smart devices for classroom learning. The participants were divided into three groups of learners:

- Using cell phones to text messages

- Using computer to send e-mails

- Speaking

The findings showed that smart phones represent a language learning resource worthy of further investigation. [38] provided an example in which learners were required to watch video lessons about English idioms on their smart phones during class. They were then asked to complete short multiple choices activities about the idioms they learned. The study found that learners' success in this task was mainly the effect of this modern media, which motivates frequent practice and studying. The smart features of mobile devices enable communicative language practice for learning a second language, as well as allowing access to authentic content and task accomplishment [14]. The results of a conducted study demonstrated that using a puzzle application game enhanced learning vocabulary and reading skills and that most learners showed positive feedback toward the application [40]. Another study on the use of text messages through smart phones for different educational purposes found that the technology turns learners from passive to active learners [43]. Moreover, it was found that edictionary apps can expand participants' vocabularies, thus improving their reading and writing skills [42]. The findings of examining the effect of employing multimedia messages service (MMS) via mobile phones in learning English vocabulary indicated that the participants that received MMS acquired more vocabulary than those who used paper and web-based tools [32]. The study carried out by [17] proved that mobile devices had a significant effect on EFL students' vocabulary retention. [31] found that using mobile phones in language learning is a promising trend for teaching and learning foreign languages. Listening, speaking, reading and culture are considered to be the main language skills that can be enhanced and taught by integrating mobile technology. The results of [2] study revealed that tablet devices provided learners with opportunities to use the foreign language in context encouraged collaborative interactions and facilitated teachers' support as well as interactions with teachers and peers. A study carried by out by [12] to determine the effect of using an interactive mobile application in improving some language skills indicated higher statistical significant 
improvements for the students. Mobile applications are useful and enjoyable educational tools for teaching English.

Some experts have found that smart phones may distract learners; students may spend time texting, surfing websites, or chatting online with their friends, rather than paying attention to the teacher. In addition to students using their mobile devices for other tasks, the instructor may be distracted by a student's actions. This causes problems for classroom management in general [39]. The most serious concerns related to the use of mobile phones in education are distracted students, cheating, low quality of Internet services, health concerns, privacy in the classroom, and technical problems [4]. It is argued that an over-dependence on mobile devices may prevent students from activating cognitive abilities like brainstorming and recalling that are essential for creativity. Likewise, smart devices can cause health problems such as headaches, insomnia and stress [30]. Among the disadvantages of using smart devices in classrooms such as problems of visibility due to small screens, high level of dependency, connectivity failure, and the extensive use of devices for non-academic purposes [23]. Furthermore, the immoderate use of mobile phones interferes with other daily life activities, converts the rules of social relationships, leads to high expenses resulting from an increase in the number of calls and messages, and affects users' health and well-being [15]. It is also argued that the slow adoption of smart devices in education is attributed to some challenges like limited computation power, limited memory capacity, short battery life, reduced input capabilities, unfriendly interfaces, and complex input methods [35].

In summary, smart phones and their applications play a great role in facilitating learning English. Literature on the uses of smart devices in learning English shows that these devices can increase learners' motivations for learning English in interesting and exciting ways. Accordingly, this study aims to provide an overview of intermediate school students'usage frequency and usage level of smart devices in order to fulfill different purposes of learning English as a foreign language.

\section{Research Question}

What are the smart device usage frequency and usage level among intermediate school students for learning English?

\section{Statement of the Problem}

Smart devices have dominated our lives since the outset of the new millennium. They are extensively possessed and used as tools for communication, information exchange, entertainment, and social interaction. With the growth of the smart devices industry, the number of smart phone users reached five billion worldwide by the end of 2017[33]. Smart devices have influenced lifestyles, traditions, culture, and education. Smart phones have a significant influence upon all aspects of education. They can be considered fantastic tools for many different educational purposes like data collection, summarizing, referencing, communication and leisure. Smart devices also 
facilitate the acquisition of essential skills such as problem solving, oral communication, writing abilities, critical thinking, global awareness and self-autonomy [11].

While smart devices provide enormously increase capabilities, the adoption of such devices in education is limited and is still considered an emerging trend [37], [23]. In Saudi Arabia, the integration of smart devices in formal education is very limited and it is only exclusive for higher education, although Saudi Arabia is ranked third in the world for smart device usage, with 72.8 percent of population using smart mobile devices [7]. Smart devices have not been officially adopted in schools due to the Saudi public educational system that prevents students from primary to secondary school from bringing their smart devices to school. Smart device usage is prohibited in schools in order to protect children and teenagers from harmful side effects such as health risks, distraction, dangerous content, and overdependence. The adoption is limited to unofficial usages outside the classroom, which depends largely on students' willingness to use and benefit from such devices in order to enhance formal and informal learning.

Reviewing the current literature, few studies have investigated the use of smart devices in Saudi higher education. The results of such studies have revealed positive attitudes, effective impacts on enhancing teaching and learning English, and meaningful opportunities for collaboration and interaction with teachers and colleagues [3], [4], [30], [2]. According to the researchers' knowledge, no study has been conducted to explore smart device usage among intermediate school students. Hence, this study aims to investigate the adoption of smart devices for language learning outside the classroom.

\section{$4 \quad$ Significance of the Study}

This paper is significant with respect to the following aspects. It seeks to increase learners' awareness about the benefits of using smart devices in learning English and help enhance learners' communication inside classrooms. It is expected that this paper will contribute to help EFL teachers develop new teaching methods and design a variety of creative activities by using applications related to English learning. Moreover, the findings of the study can help curriculum coordinators include the use of smart devices as a main part of any lesson which is expected to add a wide variety of topics and skills and give English courses more flexibility and entertainment.

\section{Delimitation of the Study}

The study is delimitated to investigating smart device usage frequency and usage level in learning English. It focuses only on female EFL learners at the intermediate level in Alaqeeq Private School, Almadinah city, KSA. 


\section{Research Methodology}

\subsection{Sample}

The study sample consisted of 50 intermediate school female Saudi students at AlAqeeq Private School in Almadinah, KSA. The participants were studying at the third level of the intermediate school, and their ages ranged from 14 to 16 . The researchers selected participants who reported that they possessed smart devices (smart phones or tablets) and that they used them for educational purposes outside the classroom. Private school students were selected in particular because smart device ownership is widespread among private school teens due to the high incomes of their families.

\subsection{Instruments}

The instrument used to collect data for this study was a questionnaire developed by the researchers. The questionnaire consisted of 20 close-ended items that were rated using a 5-point Likert scale ranging from always to never. The questionnaire validity was examined by a jury of specialists in the field of teaching English as a second/foreign language and necessary modifications were made in response to their examination. To calculate the questionnaire's reliability, the researchers implemented the Cronbach's Alpha method. The value of Cronbach's Alpha was .867, indicating that the questionnaire is highly stable (see Table 1).

Table 1. Reliability Statistics

\begin{tabular}{|c|c|}
\hline Cronbach's Alpha & No. of Items \\
\hline .867 & 20 \\
\hline
\end{tabular}

\subsection{Procedures}

To fulfill the research objective, the questionnaire was implemented among EFL female intermediate stage students in Al-Aqeeq private school who reported that they owned and used smart devices outside the classroom to learn English. The questionnaire was distributed and the collected data were analyzed statistically using SPSS (version 20). Descriptive statistics such as frequencies, means, and standard deviations were obtained to present the participants' usage frequency and the usage level of smart devices for learning English. Because a five-point Likert scale was used, the mean score was divided into five levels to enable interpretation of the usage frequency according to the mean score (see Table 2). 
Table 2. Interpretation of Usage Frequency

\begin{tabular}{|c|l|}
\hline Mean Score & \multicolumn{1}{|c|}{ Interpretation of Usage Frequency } \\
\hline $4.21-5.00$ & Always \\
\hline $3.41-4.20$ & Usually \\
\hline $2.61-3.40$ & Sometimes \\
\hline $1.81-2.60$ & Rarely \\
\hline $1.00-1.80$ & Never \\
\hline
\end{tabular}

Furthermore, the mean score was divided into three grades in order to explain the significance of smart devices usage levels (see Table 3 ).

Table 3. Significance of usage Level

\begin{tabular}{|c|l|}
\hline Mean Score & \multicolumn{1}{c|}{ Significance } \\
\hline $1.00-2.97$ & Low \\
\hline $2.98-3.98$ & Moderate \\
\hline $3.99-5$ & High \\
\hline
\end{tabular}

\section{$7 \quad$ Results and Discussion}

To answer the study's main question, "What are the smart device usage frequency and usage level among intermediate school students for learning English?, descriptive statistics such as frequencies, percentage, mean, and standard deviation for each statement were calculated and are illustrated in Table (3). The results reached the general mean of all statements (4.0860) with a standard deviation (.32406), which explains that the participants' usage frequency of smart devices is "usually" when learning English as a foreign language. Regarding the smart device usage level, the general obtained results showed high usage level among the participants.

Table 4. Descriptive Statistics

\begin{tabular}{|c|c|c|c|c|c|c|c|c|c|c|c|c|}
\hline No. & $\begin{array}{c}\text { The } \\
\text { Statement }\end{array}$ & $\mathbf{N}$ & $\begin{array}{c}\text { Al- } \\
\text { ways }\end{array}$ & $\begin{array}{l}\text { Usu- } \\
\text { ally }\end{array}$ & Sometimes & Rarely & Never & Mean & SD & Rank & $\begin{array}{l}\text { Frequen- } \\
\text { cy }\end{array}$ & Level \\
\hline \multicolumn{13}{|c|}{ Using smart devices helps me } \\
\hline st1 & $\begin{array}{l}\text { Pronounce } \\
\text { English } \\
\text { vocabulary } \\
\text { accurately. }\end{array}$ & 50 & $\begin{array}{c}14 \\
28 \%\end{array}$ & $\begin{array}{c}18 \\
36 \%\end{array}$ & $\begin{array}{c}15 \\
30 \%\end{array}$ & $\begin{array}{c}3 \\
6 \%\end{array}$ & $\begin{array}{c}0 \\
0 \%\end{array}$ & 3.8600 & .90373 & 13 & Usually & M \\
\hline st2 & $\begin{array}{l}\text { Remember } \\
\text { the words I } \\
\text { learned in } \\
\text { class. }\end{array}$ & 50 & $\begin{array}{c}29 \\
58 \%\end{array}$ & $\begin{array}{c}7 \\
14 \%\end{array}$ & $\begin{array}{c}10 \\
20 \%\end{array}$ & $\begin{array}{c}3 \\
6 \%\end{array}$ & $\begin{array}{c}1 \\
2 \%\end{array}$ & 4.2000 & $\begin{array}{c}1.0879 \\
7\end{array}$ & 8 & Usually & $\mathrm{H}$ \\
\hline st3 & $\begin{array}{l}\text { Determine } \\
\text { the correct } \\
\text { spelling of } \\
\text { English } \\
\text { vocabulary. } \\
\end{array}$ & 50 & $\begin{array}{c}31 \\
62 \%\end{array}$ & $\begin{array}{c}7 \\
14 \%\end{array}$ & $\begin{array}{c}8 \\
16 \%\end{array}$ & $\begin{array}{c}1 \\
2 \%\end{array}$ & $\begin{array}{c}3 \\
6 \%\end{array}$ & 4.2400 & $\begin{array}{c}1.1703 \\
8\end{array}$ & 6 & Always & $\mathrm{H}$ \\
\hline st4 & $\begin{array}{l}\text { Use e- } \\
\text { dictionaries } \\
\text { or apps to }\end{array}$ & 50 & $\begin{array}{c}27 \\
54 \%\end{array}$ & $\begin{array}{c}8 \\
16 \%\end{array}$ & $\begin{array}{c}6 \\
12 \%\end{array}$ & $\begin{array}{c}4 \\
8 \%\end{array}$ & $\begin{array}{l}5 \\
\%\end{array}$ & 3.9600 & $\begin{array}{c}1.3844 \\
6\end{array}$ & 11 & Usually & M \\
\hline
\end{tabular}




\begin{tabular}{|c|c|c|c|c|c|c|c|c|c|c|c|c|}
\hline No. & \begin{tabular}{|c|} 
The \\
Statement
\end{tabular} & $\mathbf{N}$ & $\begin{array}{c}\text { Al- } \\
\text { ways }\end{array}$ & $\begin{array}{l}\text { Usu- } \\
\text { ally }\end{array}$ & Sometimes & Rarely & Never & Mean & SD & Rank & $\begin{array}{l}\text { Frequen- } \\
\text { cy }\end{array}$ & Level \\
\hline & $\begin{array}{l}\text { find out the } \\
\text { meaning of } \\
\text { vocabulary. }\end{array}$ & & & & & & & & & & & \\
\hline st5 & \begin{tabular}{|l|} 
Learn \\
grammatical \\
structures.
\end{tabular} & 50 & $\begin{array}{c}15 \\
30 \%\end{array}$ & $\begin{array}{c}5 \\
10 \%\end{array}$ & $\begin{array}{c}10 \\
20 \%\end{array}$ & $\begin{array}{c}12 \\
24 \%\end{array}$ & $\begin{array}{c}8 \\
16 \%\end{array}$ & 3.1400 & $\begin{array}{c}1.4847 \\
5\end{array}$ & 16 & $\begin{array}{l}\text { Some- } \\
\text { times }\end{array}$ & M \\
\hline st6 & $\begin{array}{l}\text { Practice the } \\
\text { listening } \\
\text { skill. }\end{array}$ & 50 & $\begin{array}{c}26 \\
52 \%\end{array}$ & $\begin{array}{c}10 \\
20 \%\end{array}$ & $\begin{array}{c}5 \\
10 \%\end{array}$ & $\begin{array}{c}6 \\
12 \%\end{array}$ & $\begin{array}{c}3 \\
6 \%\end{array}$ & 4.0000 & $\begin{array}{c}1.2936 \\
3\end{array}$ & 10 & Usually & $\mathrm{H}$ \\
\hline st7 & $\begin{array}{l}\text { Develop my } \\
\text { speaking } \\
\text { skill. }\end{array}$ & 50 & $\begin{array}{c}25 \\
50 \%\end{array}$ & $\begin{array}{c}16 \\
32 \%\end{array}$ & $\begin{array}{c}5 \\
10 \%\end{array}$ & $\begin{array}{c}16 \\
32 \%\end{array}$ & $\begin{array}{c}25 \\
50 \%\end{array}$ & 4.2200 & .99571 & 7 & Always & $\mathrm{H}$ \\
\hline st8 & $\begin{array}{l}\text { Find interest- } \\
\text { ing reading } \\
\text { activities }\end{array}$ & 50 & $\begin{array}{c}19 \\
38 \%\end{array}$ & $\begin{array}{c}11 \\
22 \%\end{array}$ & $\begin{array}{c}11 \\
22 \%\end{array}$ & $\begin{array}{c}4 \\
8 \%\end{array}$ & $\begin{array}{c}5 \\
10 \%\end{array}$ & 3.7000 & $\begin{array}{c}1.3286 \\
5\end{array}$ & 15 & Usually & M \\
\hline st9 & $\begin{array}{l}\text { Improve my } \\
\text { writing skill. }\end{array}$ & 50 & \begin{tabular}{|c|}
24 \\
$48 \%$ \\
\end{tabular} & $\begin{array}{c}8 \\
16 \% \\
\end{array}$ & $\begin{array}{c}8 \\
16 \% \\
\end{array}$ & $\begin{array}{c}5 \\
10 \% \\
\end{array}$ & $\begin{array}{c}5 \\
10 \% \\
\end{array}$ & 3.8200 & \begin{tabular}{|c|}
1.3951 \\
8 \\
\end{tabular} & 14 & Usually & M \\
\hline $\begin{array}{l}\text { st1 } \\
0\end{array}$ & $\begin{array}{l}\text { Communi- } \\
\text { cate with } \\
\text { native Eng- } \\
\text { lish speakers. }\end{array}$ & 50 & $\begin{array}{c}29 \\
58 \%\end{array}$ & $\begin{array}{c}8 \\
16 \%\end{array}$ & $\begin{array}{c}5 \\
10 \%\end{array}$ & $\begin{array}{c}5 \\
10 \%\end{array}$ & $\begin{array}{c}3 \\
6 \%\end{array}$ & 4.1000 & $\begin{array}{c}1.2817 \\
4\end{array}$ & 9 & Usually & $\mathrm{H}$ \\
\hline $\begin{array}{l}\text { st1 } \\
1\end{array}$ & $\begin{array}{l}\text { Look for } \\
\text { extra learn- } \\
\text { ing activities. }\end{array}$ & 50 & $\begin{array}{c}27 \\
54 \%\end{array}$ & $\begin{array}{c}8 \\
16 \%\end{array}$ & $\begin{array}{c}6 \\
12 \%\end{array}$ & $\begin{array}{c}2 \\
4 \%\end{array}$ & $\begin{array}{c}7 \\
14 \%\end{array}$ & 3.9200 & $\begin{array}{c}1.4546 \\
2\end{array}$ & 12 & Usually & M \\
\hline $\begin{array}{l}\text { st1 } \\
2\end{array}$ & $\begin{array}{l}\text { Learn more } \\
\text { about any } \\
\text { topic. }\end{array}$ & 50 & $\begin{array}{c}34 \\
68 \%\end{array}$ & $\begin{array}{c}9 \\
18 \%\end{array}$ & $\begin{array}{c}5 \\
10 \%\end{array}$ & $\begin{array}{c}2 \\
4 \%\end{array}$ & $\begin{array}{c}0 \\
0 \%\end{array}$ & 4.5000 & .83910 & 2 & Always & $\mathrm{H}$ \\
\hline $\begin{array}{ll}\text { st1 } \\
3\end{array}$ & $\begin{array}{l}\text { Make learn- } \\
\text { ing more fun }\end{array}$ & 50 & $\begin{array}{c}34 \\
68 \%\end{array}$ & $\begin{array}{c}4 \\
14 \%\end{array}$ & $\begin{array}{c}4 \\
8 \%\end{array}$ & $\begin{array}{c}2 \\
4 \%\end{array}$ & $\begin{array}{c}3 \\
6 \%\end{array}$ & 4.3400 & $\begin{array}{c}1.1712 \\
5\end{array}$ & 5 & Always & $\mathrm{H}$ \\
\hline st1 & $\begin{array}{l}\text { Find interest- } \\
\text { ing English } \\
\text { language } \\
\text { games. }\end{array}$ & 50 & $\begin{array}{c}29 \\
58 \%\end{array}$ & $\begin{array}{c}7 \\
14 \%\end{array}$ & $\begin{array}{c}0 \\
0 \%\end{array}$ & $\begin{array}{c}9 \\
18 \%\end{array}$ & $\begin{array}{c}5 \\
10 \%\end{array}$ & 4.1000 & $\begin{array}{c}1.2975 \\
6\end{array}$ & 9 & Usually & $\mathrm{H}$ \\
\hline $\begin{array}{l}\text { st1 } \\
5\end{array}$ & $\begin{array}{l}\text { Learn infor- } \\
\text { mal English }\end{array}$ & 50 & $\begin{array}{c}22 \\
44 \%\end{array}$ & $\begin{array}{c}15 \\
30 \%\end{array}$ & $\begin{array}{c}7 \\
14 \%\end{array}$ & $\begin{array}{c}3 \\
6 \%\end{array}$ & $\begin{array}{c}3 \\
6 \%\end{array}$ & 4.0000 & $\begin{array}{c}1.1780 \\
3\end{array}$ & 10 & Usually & $\mathrm{H}$ \\
\hline $\begin{array}{l}\text { st1 } \\
6\end{array}$ & $\begin{array}{l}\text { Download } \\
\text { different } \\
\text { applications } \\
\text { for practic- } \\
\text { ing English. }\end{array}$ & 50 & $\begin{array}{c}30 \\
60 \%\end{array}$ & $\begin{array}{c}8 \\
16 \%\end{array}$ & $\begin{array}{c}6 \\
12 \%\end{array}$ & $\begin{array}{c}4 \\
8 \%\end{array}$ & $\begin{array}{c}2 \\
4 \%\end{array}$ & 4.2000 & $\begin{array}{c}1.1780 \\
3\end{array}$ & 8 & Usually & $\mathrm{H}$ \\
\hline $\begin{array}{l}\text { st1 } \\
7\end{array}$ & $\begin{array}{l}\text { Share } \\
\text { knowledge } \\
\text { and ideas } \\
\text { with my } \\
\text { classmates. }\end{array}$ & 50 & $\begin{array}{c}24 \\
48 \%\end{array}$ & $\begin{array}{c}11 \\
22 \%\end{array}$ & $\begin{array}{c}7 \\
14 \%\end{array}$ & $\begin{array}{c}7 \\
14 \%\end{array}$ & $\begin{array}{c}1 \\
2 \%\end{array}$ & 4.0000 & $\begin{array}{c}1.1780 \\
3\end{array}$ & 10 & Usually & $\mathrm{H}$ \\
\hline \begin{tabular}{l|l}
$s t 1$ \\
8
\end{tabular} & $\begin{array}{l}\text { Send as- } \\
\text { signments to } \\
\text { my teacher . }\end{array}$ & 50 & $\begin{array}{c}38 \\
76 \%\end{array}$ & $\begin{array}{c}5 \\
10 \%\end{array}$ & $\begin{array}{c}4 \\
8 \%\end{array}$ & $\begin{array}{c}2 \\
4 \%\end{array}$ & $\begin{array}{c}1 \\
2 \%\end{array}$ & 4.5400 & .95212 & 1 & Always & $\mathrm{H}$ \\
\hline $\begin{array}{l}\text { st1 } \\
9\end{array}$ & $\begin{array}{l}\text { Receive } \\
\text { feedback } \\
\text { from my } \\
\text { teacher and }\end{array}$ & 50 & $\begin{array}{c}33 \\
66 \%\end{array}$ & $\begin{array}{c}9 \\
18 \%\end{array}$ & $\begin{array}{c}7 \\
14 \%\end{array}$ & $\begin{array}{c}1 \\
2 \%\end{array}$ & $\begin{array}{c}0 \\
0 \%\end{array}$ & 4.4800 & .81416 & 3 & Always & $\mathrm{H}$ \\
\hline
\end{tabular}


Paper-Smart Device Usage Frequency and Usage Level for Learning English

\begin{tabular}{|c|c|c|c|c|c|c|c|c|c|c|c|c|}
\hline No. & $\begin{array}{c}\text { The } \\
\text { Statement }\end{array}$ & $\mathbf{N}$ & $\begin{array}{c}\text { Al- } \\
\text { ways }\end{array}$ & $\begin{array}{l}\text { Usu- } \\
\text { ally }\end{array}$ & Sometimes & Rarely & Never & Mean & SD & Rank & $\begin{array}{l}\text { Frequen- } \\
\text { cy }\end{array}$ & Level \\
\hline & colleagues. & & & & & & & & & & & \\
\hline $\begin{array}{l}\mathrm{st} 2 \\
0\end{array}$ & \begin{tabular}{|l|} 
Design \\
presentations \\
or concept \\
maps.
\end{tabular} & 50 & $\begin{array}{c}36 \\
72 \%\end{array}$ & $\begin{array}{c}5 \\
10 \%\end{array}$ & $\begin{array}{c}3 \\
6 \%\end{array}$ & $\begin{array}{c}5 \\
10 \%\end{array}$ & $\begin{array}{c}1 \\
2 \%\end{array}$ & 4.4000 & $\begin{array}{c}1.1065 \\
7\end{array}$ & 4 & Always & $\mathrm{H}$ \\
\hline \multicolumn{2}{|c|}{$\begin{array}{l}\text { Valid N (list- } \\
\text { wise) }\end{array}$} & 50 & & & & & & 4.0860 & .32406 & & Usually & High \\
\hline
\end{tabular}

As illustrated in Table (3), the statements were ranked in a descending order according to the mean score. It is noticeable that the item with the highest usage frequency according to the mean score is using smart devices helps me send assignments to my teacher ( $M$ 4.54, SD .95212.), revealing that the respondents agreed that they always used smart devices to send assignments. This level of usage is high. The majority of students prefer to send assignments to their teachers using smart devices because they present them with flexibility in time and place. They can also check and look for information. This finding is in accordance with [12] in terms of the flexibility to learn any time and place, getting access to information, and recording data.

The second highest usage frequency item in rank was using smart devices helps me learn more about any topic ( $M$ 4.50, SD.83910), indicating that the respondents agreed that they always use smart devices to learn or to look for information about any topic. This level of usage is high among students. The majority of students always use smart devices to search for information or to gain more knowledge about topics or the lesson they are studying. This finding is quite consistent with the findings of [27].

The third item according to usage frequency is using smart devices helps me receive feedback from my teachers and colleagues (M 4.48, SD.81416). This shows that students agreed that they can always easily get feedback from their teachers and colleagues if they use smart devices because they know that most teachers use smart devices to stay contacted with their students and provide them with immediate evaluations of their assignments. As a result, students are able to receive more direct and reliable evaluations. The usage level of this item is high. This finding corresponds with the findings of [26] in terms of the advantages of smart devices in providing users with quick or immediate feedback to users.

The item that obtained the fourth usage frequency rank is using smart devices helps me design a presentations or concept maps ( $M 4.40, S D 1.10657)$. The majority of students always use smart devices to fulfill their courser requirements, which may entail preparing presentations or concept maps. Smart devices enabled them to gather information about their presentations or search for appropriate designs. They are a real assistance for them with their assignments. The level of this usage is high. These findings correspond with [29], who indicated that mobile concept mapping approaches provided a more effective learning tool to reform and present vocabulary.

The fifth item in the rank according to usage frequency is using smart devices helps me make learning more fun $(M 4.34, S D$ 1.17125). Respondents agreed that they always spend interesting learning time when they use smart devices because they add fun and pleasure to the learning process. The level of usage for this item is high. 
The sixth item in usage frequency rank is using smart devices helps me determine the correct spelling of English vocabulary ( $M$ 4.24, SD 1.17038). The respondents agreed that they always use smart devices to get a direct correction in spelling because there are numerous programs and apps that assist students in enhancing their vocabulary learning and instruct them how to write correctly. The usage level of this item is high. As mentioned in [24] study, students represent an effective development in collaborative writing when they use WhatsApp for the purpose of improving writing.

The item that got the seventh usage frequency is using smart devices helps me develop my speaking skill (M 4.22, SD .99571). The respondents agreed that they always use smart devices to develop their speaking skill. The usage level of this item is high. The participants preferred to use smart devices apps to speak and contact with native speakers. According to [6], technology provides different tools to help second language learners outside traditional classroom methods; one of which is using smart phones to develop learners' oral skills.

The statements (2-16) came in 8th according to usage frequency. The items are using smart devices helps me remember the words I learned in class and using smart devices helps me download different applications for practicing English. The mean of both statements is (4.20). The respondents agreed that they usually use smart devices to learn vocabulary and that they can use different applications to practice foreign language. The usage level of both items is high. Both statements indicated that students prefer to learn and practice English language while utilizing smart devices because mart devices are more patient than teachers. Students can practice as much as they need. Also, the features in smart devices offer information related to worlds that have become stuck in students' minds after watching or hearing many details about such words. [9] maintain that using iPads in education encourages lifelong learning among second language learners. It is obvious that learning through iPads or tablets has a positive effect on the process of learning another language.

The 9th rank in usage frequency is for two statements $(10-14)$. The items are using smart devices helps me communicate with native English speakers and using smart devices helps me find interesting English language games. The mean is (4.10) for both statements. This result shows that the respondents agreed that they usually use smart devices to communicate and interact with native speakers and to play language learning games. The mean score indicates a high usage level among students.

The statements $(6-15-17)$ came in 10th place according to usage frequency rank. The items are using smart devices helps me practice the listening skill, using smart devices helps me learn informal English and using smart devices helps me share knowledge and ideas with my classmates. The mean of the three items is (4.00). The participants agreed that they usually use smart devices for several purposes such as practicing oral skills, learning informal English, and sharing ideas with their colleagues. The mean score of the three indicates a high usage level among students.

The 11th usage frequency rank is for the item using smart devices helps me use edictionaries or Apps to determine the meaning of English vocabulary (M 3.96, SD 1.38446). The respondents agreed that they usually use smart devices to find the meaning of new vocabulary through electronic dictionaries or translation apps. The usage level among students is moderate. 
The item using smart devices helps me search for extra learning activities (M 3.92, SD 1.45462) had the 12th usage frequency rank. The majority of students found that smart devices provided them with additional useful learning activities that may enhance their learning and improve their performance. The usage level among students is moderate. [28] stated that active learning would be possible for students if they use smart phones because they provide them with different possible activities that support student-cantered learning.

The 13th usage frequency rank is for the item using smart devices helps me pronounce English vocabulary accurately (M 3.86, SD.90373). The respondents agreed that they usually use smart devices to listen to and practice accurate pronunciation of vocabulary. This is due to the existence of advanced apps and websites that enable students to correct their pronunciation and practice as much as they can. The usage level among students is moderate.

The 14th item in the usage frequency rank is using smart devices helps me improve my writing skill (M 3.82, SD 1.39518). The participants agreed that they usually use smart devices to enhance and improve their writing abilities as they can search for writing activities for different learning styles and find error-correction tools. Students can also share their writings with colleagues and receive comments, assistance or feedback. They can check their writing accuracy through available apps.

The statement that was ranked 15th in usage frequency rank is using smart devices helps me find interesting reading activities (M 3.70, SD 1.32865). The participants usually practice reading and their usage level is moderate. They can access websites to read, search for reading comprehension activities, and use applications that offer help and guidance in enhancing reading skills. This finding is aligned with that of [19] who investigated the effect of using mobile technology in reading classroom by using various mobile features and applications. The results indicated that mobile technology slightly helped improve students' reading performance.

The 16th usage frequency rank is for the item using smart devices helps me learn grammatical structures (M 3.14, SD 1.48475). The respondents sometimes use smart devices to learn grammar and their usage level is moderate. Smart devices help students find elaborate and detailed explanation of grammatical structures. They can practice until they comprehend or master the structure and then access quizzes to evaluate their understanding.

\section{Conclusion}

The massive increase in the possession and use of smart devices among students of different ages and various social backgrounds has opened the door for marvelous opportunities in foreign language learning. Because of smart devices' size, features, and capabilities, students have integrated these into their learning processes. Hence, this study intended to investigate smart device usage frequency and level among students in intermediate school for learning English. Through analyzing the data collected from a questionnaire, this study found that the usage level of smart devices among students is high. Intermediate school students have usually used smart devices outside 
the classroom to facilitate language learning. The results of this study indicated that the highest usage frequency of smart devices was for connectivity, research, arranging presentations, and adding fun to the learning process. Smart devices make students feel more comfortable because they have the capacity to connect students and teachers and create more flexible learning environment. Students can submit assignments and receive feedback anytime and anywhere. Students also use such devices for research purpose in order to gain more knowledge about various topics. In addition, students used these devices to search for countless learning materials, activities, and applications related to their lessons. For students, smart devices are beneficial for preparing assignments like presentations, concept maps, and work sheets. They also add fun and enjoyment to the learning process.

The results also indicated that the skills that were most frequently used with smart devices were respectively vocabulary, listening and speaking. On the other hand, the skills that obtained the least usage frequency for smart devices were grammar, reading, and writing. This finding is very significant because it reflects students' awareness that aural skills (listening and speaking) are vital for developing fluency and fostering the use of English for communication. According to the participants, using smart devices is effective for enhancing listening and speaking skills. Smart devices create relevant and real learning environment because they provide students with a variety of installed apps, authentic materials, podcast tools, and interactive activities. Using smart devices, students can interact and communicate with native English speakers. Smart devices provide learners with comprehensible input and offer opportunities to negotiate meaning through interaction with real people. This contrasts learning aural skills in language classrooms which are unrealistic communication environment. In language classroom, students can neither listen to authentic language nor communicate with native speakers. They can only listen to recorded speeches with CD players which are more formal and unauthentic. They can only practice speaking through interacting with their teacher and classmates who are non-native speakers.

The results of the current study revealed that the high usage level of smart devices among students for learning English is elated to students' awareness and familiarity with the enormous capabilities and incredible opportunities that smart devices provide for language learning. This is in aligned with the results of previous studies [5], [12], [1], [2], [31], [30], [34], [16], [3], [4]. This study recommends that education policy makers design effortless and attractive language learning applications that are appropriate to students' needs. They should offer training courses to equip teachers with the necessary skills to help students use smart devices in learning. Language teachers should realize that preventing smart devices in schools does not imply discouraging or ignoring integrating such devices in learning. On the contrary, teachers should guide students to benefit from smart devices in enhancing their formal and informal learning. They can direct students to install useful applications and to access advantageous learning material and activities outside of class time. 


\section{$9 \quad$ References}

[1] Ababneh, S. (2017). Using mobile phones in learning English: The case of Jordan. Journal of Education and Human Development, 6(4), 120-128.

[2] Albadry, H. (2017). An investigation into the role of tablet devices in facilitating collaborative learning in EFL course. International Journal of Emerging Technologies in Learning, 12(4), 39-53. https://doi.org/10.3991/ijet.v12i04.6732

[3] Al-Fahad, F. N. (2009). Students' attitudes and perceptions towards the effectiveness of mobile learning in King Saud University, Saudi Arabia. The Turkish Online Journal of Educational Technology, 8(2), 111-119.

[4] Alsadoon, H. (2012). Use of cell phones in at King Saud University in the kingdom of Saudi Arabia. PhD Dissertation. The Patton College of Education of Ohio University.

[5] Alshabeb, A. \& Almaqrn, R. ( 2018). A study of EFL Saudi students' use of mobile social applications for learning. Arab World English Journal, 4, 214-226. https://doi.org/10.2409 3/awej/call4.17

[6] Al-Zahrani, A. S. (2015). Smartphones wandering at the mall: A case study investigating the use of smartphones on English oral learning skills in a collaborative mobile-assisted language learning environment (Doctoral dissertation, Northern Illinois University).

[7] Arab News. (2017). Saudi Arabia ranks third globally for Smartphone use. http://www. arabnews.com/node/1075126/corporate-news.

[8] Arpaci, I. (2014). A comparative study of the effects of cultural differences on the adoption of mobile learning. British Journal of Educational Technology, 46(4), 699-712. https://doi.org/10.1111/bjet.12160

[9] Auquilla, D. P. , \& Urgilès, G. E. (2017). The use of iPad and applications for English Language Education. Theory and Practice in Language Studies, 7(9), 709-715. https://doi. org/10.17507/tpls.0709.01

[10] Bebell, D. (2005). Technology promoting student excellence: An investigation of the first year of 1:1 computing in New Hampshire Middle Schools. Boston, MA: Technology and Assessment Study Collaborative, Boston College. http://www.bc.edu/research/intasc/re searchprojects/nhLaptop/nhtpse.shtml.

[11] Brown, J. (2005). Mobile industry status : Where we are and where we are going? Retrieved from http://mlearnopedia.com/presentation/MobileIndustry3-1-03.

[12] Cavus, N., \& Ibrahim, D. (2009). M-Learning: An experiment in using SMS to support learning new English language words. British Journal of Educational Technology, 40, 7891. https://doi.org/10.1111/j.1467-8535.2007.00801.x

[13] Chen, C.M., \& Hsu, S.-H. (2008). Personalized intelligent mobile learning system for supporting effective English learning. Educational Technology \& Society, 11 (3), 153-180.

[14] Chinnery, G. (2006). Emerging technologies going to the MALL: Mobile assisted language learning. Language Learning \& Technology, 10 (1), 9-16.

[15] Chóliz, M. (2012) Mobile-phone addiction in adolescence: The test of mobile phone dependence. Prog Health Sci, 2 (1), 33-44.

[16] Dang, T. (2013). Toward the use of mobile phones for learning English as a foreign language: Hesitation or welcome? Language in India, 13 (10), 463

[17] Hashemi, M., \& Abbasi, M., (2013). The role of the teacher in alleviating anxiety in language classes. International Research Journal of applied and Basic Sciences, 4(3), 640646. Retrieved from: http://www.irjabs.com/files_site/paperlist/r_726_130328102911.pdf

[18] Hashemi, M., Azizinezhad, M., Najafi, V., Nesari, A. (2011). What is mobile learning? Challenges and Capabilities. Social and Behavioral Sciences, 30, 2477-2481. https://doi. org/10.1016/j.sbspro.2011.10.483 
[19] Hazaea, A. \& Alzubi, A. (2016). The effectiveness of using mobile EFL learners' reading practices in Najran University. English Language Teaching, 9 (5), 8-21. https://doi.org /10.5539/elt.v9n5p8

[20] Holum, A. \& Gahala, J. (2001) Critical issue: Using technology to enhance literacy instruction. North Central Regional Educational Laboratory website. Retrieved from: http://www.ncrel.org/sdrs/areas/issues/content/cntareas/reading/li300.htm

[21] Jobe, H., \& Peck, K. (2008). Classrooms for the Future (CFF): Preliminary Results. Presentation at the Pennsylvania Educational Technology Expo and Conference, Hershey, PA, February, 2008.

[22] Johnson, L., Smith, R., Willis, H., Levine, A., \& Haywood, K. (2011). The 2011 horizon report. Austin, TX: The New Media Consortium.

[23] Jovanović, I. (2017). Learning foreign languages via mobile devices- attitude and experience of students of higher business school of professional studies in Leskovac. The 10th International Conference "Science and Higher Education in Functional of Sustainable Development" 06-07 October, Serbia.

[24] Khalil, M. \& Samadi, F. (2017). The Effect of Using Online Collaborative Tasks on Incidental Vocabulary Learning of Impulsive vs. Reflective Iranian EFL Learners. International Journal of Applied Linguistics and English Literature, 6 (6), 127-133. https://doi.org/10.7575/aiac.ijalel.v.6n.6p.127

[25] Kiernan, P.J., \& Aizawa, K. (2004). Cell phones in task based learning-Are cell phones useful language learning tools?. ReCALL, 16 (1), 71-84. https://doi.org/10.1017/s095834 4004000618

[26] Kukulska-Hulme, A \& Shield, L. (2004). Usability and pedagogical design: Are language learning websites special? In: Proceedings of ED-MEDIA 2004-World Conference on Educational Multimedia, Hypermedia Telecomm-unications (Cantoni, L. and McLoughlin, C. eds.), Association for the Advancement of Computing in Education (AACE), Lugano, Switzerland, pp. 4235-4242.

[27] Kumar, A., Tewari, A., Shroff, G., Chittamuru, D., Kam, M. \& Canny, J. (2010). An exploratory study of unsupervised mobile learning in rural India. proceedings. Conference on Human Factors in Computing Systems 2010, April 10-15, 2010, Atlanta, Georgia, USA. http://bid.berkeley.edu/files/papers/CHI2010a.pdf https://doi.org/10.1145/1753326.17534 $\underline{35}$

[28] Kurniawan, M. (2018). The use of mobile phone in English language lesson: A shift from teacher-centred to student-centred through mobile learning. https://doi.org/10.1051/shs conf/20184200076

[29] Liu, P. (2016). Mobile English vocabulary learning based on concept-mapping strategy. Language Learning \& Technology, 20(3), 128-41.

[30] Nalliveettil, G. \& Alenazi, T. (2016). The impact of mobile phones on English language learning: Perceptions of EFL undergraduates. Journal of Language Teaching and Research, 7 (2), 264-272. https://doi.org/10.17507/jltr.0702.04

[31] Saidouni, K. \& Bahloul, A. (2016). Teachers and students' attitudes toward using mobile assisted language learning in higher education. Arab World English Journal, 3, 123-140. https://doi.org/10.2139/ssrn.2822983

[32] Saran, M., Cagiltay, K. \& Seferoğlu, G. (2008). Use of mobile phones in language learning: Developing effective instructional materials. Fifth IEEE International Conference on Wireless, Mobile, and Ubiquitous Technology in Education (wmute 2008), Beijing, 2008, pp. 3943. https://doi.org/10.1109/wmute.2008.49

[33] Saudi Gazette. (2017). Smart phone users worldwide 2020. Available at: http://saudi gazette.com.sa/article/175451/61bn-smartphone-users-worldwide-by-2020. 
[34] Shraim, K. \& Cormpton, H. (2015). Perceptions of using smart mobile devices in higher education teaching: A case study from Palestine. Contemporary Educational Technology, $6(4), 301-318$.

[35] Tabor, S. (2016). Making mobile learning work: Student perceptions and implementation factors. Journal of Information Technology Education: Innovations in Practice. 15(1), 7598. https://doi.org/10.28945/3524

[36] Taxler, J. (2007). Defining, discussing and evaluating mobile learning: The moving finger writes and having writ . International Review of Research in Open and Distance learning, 8 (2), 1-12. https://doi.org/10.19173/irrodl.v8i2.346.

[37] Thomas, D., Singh, L., \& Gaffar, K. (2013). The utility of the UTAUT model in explaining mobile learning adoption in higher education in Guyana. International Journal of Education and Development using Information and Communication Technology, 9 (3), 71-85.

[38] Thornton, P. \& Houser, C. (2005). Using mobile phones in English education in Japan. Journal of Computer Assisted Learning, 21, 217-228. https://doi.org/10.1111/j.13652729.2005.00129.x

[39] Tindell, D. \& Bohlander, R. W. (2012) The Use and Abuse of Cell Phones and Text Messaging in the Classroom: A Survey of College Students, College Teaching, 60 (1), 1-9. https://doi.org/10.1080/87567555.2011.604802

[40] Todd, R. \& Tepsuriwong, S. (2008). Mobile mazes: investigating a mobile phone game for language learning. Computer-Assisted Language Learning Electronic Journal, 10 (1), 116.

[41] Waddoups, G. , Wentworth, N., Earle, R. (2004). Teaming with Technology. A case study of a faculty design team developing electronic portfolios. Journal of Computing in Teacher Education, 20(3), 113-120

[42] Wang, J. (2012). The use of e-dictionary to read e-text by intermediate and advanced learners of Chinese., Computer Assisted Language Learning, 25 (5), 475-487. https://doi. org/10.1080/09588221.2011.631144

[43] Wang, M., Shen, R., Novak, D., and Pan, X. (2009). The impact of mobile learning on students' learning behavior and performance: Report from a large blended classroom. British Journal of Educational Technology, 40(4), 673-695. https://doi.org/10.1111/j.14678535.2008.00846.x

[44] Woodill, G. (2013). The unique affordances of mobile learning understand how to leverage them prior to design and development. Retrieved from: http://floatlearning.com/2013/11/ the-unique-affordances-of-mobile-learning/ https://doi.org/10.1002/9781119036883.ch15

\section{Authors}

Areej Alsanosi is a master student who is currently working as English teacher in general education in south of Saudi Arabia. She obtained her Bachelor degree in English from Taibah University in 2011.

Abeer Alharbi is a researcher who has been working as an English teacher in Almahad District since 2017. She obtained her B.A degree in English from the Faculty of education, Taibah University in 2011.

Dr. Safaa Mohammad Alhebaishi received the M.S. and Ph-D degrees in TEFL. Currently, she is an associate professor in Curricula and Teaching Methods Dept., at Taibah University, Almadinah, KSA. She is interested in research in second /foreign 
language classroom, individual differences in learning a foreign language, innovative teaching methods, and integrating technology in language classroom.

Article submitted 2018-12-15. Resubmitted 2019-05-27. Final acceptance 2019-06-19. Final version published as submitted by the authors. 